MedieKultur | Journal of media and communication research | ISSN 1901-9726

Article - Theme section

\title{
Streaming across industries
}

Streaming logics and streaming lore across the

music, film, television, and book industries

\section{Vilde Schanke Sundet and Terje Colbjørnsen}

\author{
MedieKultur 2021, 70, 12-31
}

Published by SMID | Society of Media researchers In Denmark | www.smid.dk The online version of this text can be found open access at www.mediekultur.dk

\begin{abstract}
This article explores streaming across the cultural industries, drawing on 39 interviews with CEO/top-level industry executives working in the Norwegian music, film, television, and book industries. We examine two broad questions: What do key industry players see as the main opportunities and challenges of streaming? To what extent do industry players compare with and learn from other industries when making sense of, and seeking solutions to, the main challenges? Drawing on theories of media industry logics and industry lore, the article identifies a collective understanding of turmoil and uncertainty. While informants across industries form similar notions about the impact of streaming and emphasise the need to learn from other industries, solutions to challenges are typically sought within industryspecific frames. Our findings suggest that even if streaming is a cross-industrial trend, strategies are based on industry-specific logics and notions.
\end{abstract}

\section{Keywords}

Cross-industries, cultural industries, elite interviews, industry logics, media industries, streaming, streaming lore 


\section{Introduction}

Streaming is changing the cultural industries, but in diverse ways and at different paces. While the shift towards streaming is most pronounced in the music industry (Hagen, 2015; Spilker, 2018; Wikström, 2013), the film and television industries have similar trends (Bruun, 2020; Johnson, 2019; Sundet, 2021), and even the book industry is seeing the impact of the streaming model, particularly for digital audiobooks (Colbjørnsen, 2015; Have \& Pedersen, 2020; Tattersall \& Nolin, 2020). Across industries, global platforms such as Spotify, YouTube, Netflix, Disney and Amazon have gained vital positions, challenging incumbent industry players - content creators, publishers/distributors, and national streaming providers - and their business models and practices (Cunningham \& Silver, 2013; Evens \& Donders, 2018; Lobato, 2019). National players face the central dilemma of needing to harness the opportunities of streaming - and alleviating the unfortunate consequences - and to do so, they need to make sense of the developments taking place.

This article explores how key industry players across various cultural industries make sense of, and form, notions about streaming, using Norwegian music, film, television, and book industries as the basis for discussion. While streaming is an increasingly popular research topic, few studies have adopted a cross-industrial approach to investigate how streaming affects industry players from various fields (see, however, Colbjørnsen, 2020; Herbert et al., 2019). The four selected industries are all rooted in different paradigms of cultural production - the publishing model, the flow model and the written model (Miège, 1989, p. 146-147) - but digitalisation and streaming erase some of their historical differences. Taking a comparative perspective allows us to examine not only how certain actors handle streaming challenges, and why some succeed while others struggle, but also to see how the shift to streaming plays out in different media contexts in the same national market.

The article combines perspectives on the streaming model (Colbjørnsen, 2020; Herbert et al., 2019; Spilker \& Colbjørnsen, 2020) with studies of media industries (Havens et al., 2009; Herbert et al., 2020) and studies of industry sensemaking (Weick, 1995), drawing on concepts such as "working notions" (Sundet \& Ytreberg, 2009) and "industry lore" (Burroughs, 2019; Havens \& Lotz, 2012). It is motivated by the need to unpack takenfor-granted industry perceptions on recent technology, and to investigate how such common-sense ideas affect strategies and practices. Two research questions guide the article. First, what do key industry players see as the main opportunities and challenges of streaming? Second, to what extent do industry players compare with and learn from other industries when making sense of, and seeking solutions to, the main challenges? A key aim of the article is to identify collective understandings and examine whether industry players draw on experiences across industries to define strategies, seek out business opportunities and counter challenges.

To investigate these questions, the article draws on 39 interviews with CEOs/top-level Norwegian industry executives and decision-makers, representing the most significant 
music, film, television, and book organisations in Norway, including major record labels, production companies, broadcasters, book publishers, streaming platforms, and interest organisations. The Norwegian market is small but technologically mature, and one where streaming has taken a firm hold across industries (Lüders et al., 2021). Trends and strategies in this market may therefore serve to predict how other markets may develop.

The Norwegian streaming music market is dominated by global providers such as Spotify, Apple Music and Tidal, with free-to-use YouTube also a significant player. The Norwegian streaming television market is dominated by a mix of services provided by national and public service broadcasters (NRK player, TV 2 Sumo) and commercial broadcasters (Dplay, Viaplay) —and global platforms (Netflix, HBO Nordic, Disney+, Amazon, YouTube). The Norwegian streaming film market is fragmented, and the global players pay little attention to Norwegian films. There is a wide array of services available for streaming films, many (such as Netflix and HBO Nordic) offering a combination of television and film content. Public service broadcasters and regional broadcasters (like those for television) add to the mix. The Norwegian streaming book market is dominated by national and regional players, and it is fast-growing. Regional players such as Storytel and Fabel compete with global providers such as Amazon.

\section{Theoretical approach: Industry logics and industry lore}

\section{Industry logics}

The music, film, television, and book industries have different dynamics (Hesmondhalgh, 2019) or logics (Herbert et al., 2019; Thompson, 2010), indicating that the industries work by different rules, and accordingly that the impact of streaming on each industry may also differ. The term "industry logics" builds on Miège's (1989) work on cultural industries, where he organises media production into three models-the publishing model, the flow model, and the written model-and centres each model in different industries with different logics: films, books and music in the publishing model; radio and television in the flow model; newspapers and magazines in the written model. Miège shows how different media industries employ particular business models that shape how media are made, circulated and consumed (see also Herbert et al., 2020, p. 114-116). To some extent, streaming can be said to interfere with these traditional industry logics. For instance, Lotz (2017, p. 19) argues that streaming removes television from the characteristics of the flow model and brings it closer to the publishing model (see also Kompare, 2006).

Different industry logics partly account for why cross-industry approaches are needed; we cannot conclude insights from one domain to another. Cross-industrial studies may even bring out industry logics more clearly than industry-specific studies, including sectorial similarities and differences (Herbert et al., 2019). In a comparative study of streaming in the film, television and music industries, Herbert et al. (2019) find the user experience to be a common denominator across the three industries. Differences derive from diverg- 
ing business practices associated with each sector, such as how content creation is organised and how revenues are distributed. The authors conclude by noting, "the underlying IP relations between the services and the content creators allow very different libraries and thus competitive conditions" (Herbert et al., 2019, p. 363). The most clearly visible indication of the different configurations of streaming services for film, television, music and digital books is that competition and content catalogues differ markedly: Music services such as Spotify, Apple Music, Deezer and Tidal all offer comparable databases containing the most significant artists and labels. Content offerings in television and film, as well as ebook and audio book streaming, are mostly non-overlapping between competing services (see more, Colbjørnsen, 2020).

Sector-specific media and cultural policy regimes also affect the shift to streaming (Colbjørnsen et al., 2020; Evens \& Donders, 2018). While media and cultural policy are critical for all four industries examined here, the scope and application are somewhat different: In Norway, cultural policy on literature is comprehensive and applied at several stages in the production and dissemination of books (Colbjørnsen et al., 2020). Cultural policy for film and television primarily targets public service institutions and content production (Moseng, 2017). The music industry is typically associated with commercial markets, however, there is substantial organisation to subsidise and support Norwegian musicians, among others, in order to strengthen specific genres (e.g., jazz, classical music), support music festivals and promote dissemination abroad (Kjus, 2018).

Despite the differences noted above, the music, film, television, and book industries are comparable sectors regarding the shift to streaming. As part of what Hesmondhalgh (2019) calls "the core cultural industries", they compete for many of the same resources, including the attention of audiences - and a piece of their media budgets. Streaming services in multiple sectors can be said to offer "temporary and contingent on-demand access to vast content databases for a fixed fee paid on a regular basis, or for exposure to advertising, and through an internet-connected device" (Colbjørnsen, 2020, p. 5). Within the television industry, public service broadcasters also operate streaming services (D'Arma et al., 2021). While specific business models and technological set-ups may vary, the service experience and basic infrastructure is similar in offering choice and convenience on a single platform (Herbert et al., 2019; Fagerjord \& Kueng, 2019). The necessity of maintaining a vast selection and updating the database creates a constant need for content. Streaming services operate with a specific business model where customers typically pay a flat fee for a content bundle. Revenues are distributed between the streaming provider, intermediaries such as publishers, production companies or record companies, and content creators such as artists, authors, scriptwriters etc.

\section{Sensemaking, industry lore, and working notions}

Planning for the future is at the core of capitalist dynamics, and goes beyond rational strategising, as it requires actors to imagine a future to serve as a reference point for 
their decision-making (Beckert, 2016). The importance of trying to think ahead arguably becomes even more pertinent with emerging technologies. Adapting to the streaming model requires executives across industries to make sense of and try to anticipate future developments. Several terms and notions can be used to invoke and conceptualise these visions of the future. Here, we build on Weick's (1995) concept of sensemaking as an overarching term to denote ways of structuring the unknown so as to be able to act in it. This perspective is mostly organisational, dealing with how individual biases and heuristics affect organisational structure and behaviour.

Sensemaking practices can, however, also be observed at an industry level. Here, the concepts "industry lore" (Havens, 2008; Havens \& Lotz, 2012), "trade stories" (Caldwell, 2008) and "working notions" (Sundet \& Ytreberg, 2009) contribute approaches to understanding how industries make sense of developments on a collective scale. Trade stories can be analysed as narrative genres that help practitioners make sense of their industry. As Caldwell (2008, p. 37) says, "Various narrative trade genres (making-it sagas, coming-ofage tales, against-all-odds technical anecdotes, and cautionary tales) also help practitioner communities weather change in the face of technological flux and economic instability". Similarly, the concept working notions (Sundet \& Ytreberg, 2009) denotes key components in professional discourse with strategic functions. Industry notions typically also cross into promotion strategies and branding (Grainge \& Johnson, 2015), as companies set out to discursively further their interests.

We will examine lore and notions that cut across industries, constituting a cross-media sensemaking vocabulary, as an interesting aspect of digital media convergence. Burroughs (2019) focuses on the television industry to examine a potentially useful notion in this regard, which he terms "streaming lore". The term has many similarities to Havens' (2008) term industry lore, which he defines as "the conventional knowledge among industry insiders about what kinds of media culture are and are not possible, and what audiences that culture will and will not attract" (quoted in Burroughs, 2019, p. 3). Streaming lore, as Burroughs (2019, p. 4) defines it, is a "re-articulation of industry lore". Burroughs shows how Netflix uses the streaming lore of the algorithmic audience to "discursively position audiences as consumers" (p. 11). The Netflix example indicates how sensemaking notions have strategic consequences, meaning that the way executives want to see things often influences the way they respond (see also, Ang, 1991). Relatedly, Tryon (2015) claims that Netflix has continuously re-branded itself as "the future of television" and as something different (and better) than traditional (linear) television, e.g. by linking the practice of binge-viewing to quality television. Similarly, Sundet (2021) finds that the Norwegian public broadcaster NRK operates with a perception of its streaming audience as active, deliberate, and unfaithful, legitimating both high-budget "world-class" content strategies and small-budget niche content strategies. Taking a more general approach, Enli and Syvertsen (2016) stress the need to address working notions and industry lore critically, as these are often promoted by players that benefit from their realisation. 


\section{Method: Elite interviews with industry decision-makers}

The information reported in this article is from 39 qualitative elite interviews with Norwegian CEO/top-level industry executives and decision-makers. Interviewing industry elites is a valuable method for gaining in-depth insight and knowledge into industry perceptions and strategies that can often be hard for researchers to reach through other sources and methods. Elite informants possess a special kind of industry knowledge that cannot easily be replaced-they are "exclusive" (Bruun, 2016, p. 132-135). All the same, elite interviews involve potential pitfalls and require critical analysis. To start with, interviewing industry elites runs the risk of failing to differentiate between personal and company perspectives, and between planned and actual strategies and practices. Furthermore, these informants possess power, have leading positions and typically present arguments that reflect corporate interests - they are gatekeepers of information. As argued by Bruun (2016), elite informants must be expected to have "agendas" in interviews, and they must be regarded as "part of the research findings" (p. 142). As indicated by our research questions, a key aim of this study is to uncover these industry agendas and the way they are presented through sensemaking, working notions and industry lore.

Informants were selected in this study to represent the most significant music, television, film, and book organisations in Norway (see Table 1 for an overview of informants). We also sent interview requests to representatives of global streaming providers holding key positions in Norway-HBO Nordic, YouTube, Netflix, Tidal, and Spotify-however, except for Spotify, they all declined to take part. Our study thus reflects the common but crucial problem of denied access and "cold calling" (Bruun, 2016) when accessing elite informants, which proves particularly challenging when approaching "new" media organisations where access and trust is yet to be obtained.

All the interviews were conducted within four months, from October 2019 to February 2020, just before the covid-19 pandemic led to lockdown in Norway. The informants are thus reflecting on a pre-covid-19 streaming situation. Most of the informants were interviewed face-to-face, though a few were interviewed by phone. All consented to being named in the study.

Interviews lasted approximately 60 minutes. We followed the same structured interview guide in all interviews, designed to allow for comparison across institutions and industries. The guide included two sets of questions. First, we asked 17 open-ended questions, including questions on the main benefits and challenges of streaming, and about the degree to which they looked to other industries for lessons and best-practice approaches. Second, we asked informants to respond to 40 claims on streaming designed to map and uncover working notions, to which the informants were asked to fully or partly agree or disagree (e.g. "The streaming market is changing so rapidly that it is difficult for those working in the industry to keep up"). ${ }^{1}$ All answers to the open-ended

138 of the 39 informants responded to these claims. 
questions were transcribed and coded in NVivo 12. The analysis combined inductive and deductive approaches. First, codes were inductively identified reading the transcripts. Next, these codes were linked to theoretical concepts of relevance for our objective of investigating and conceptualising streaming lore (see Kiberg, 2020 for another analysis based on parts of the same material).

Table 1. Overview of informants with abbreviations, titles and organisations

\begin{tabular}{|c|c|c|c|c|}
\hline Industry & Name & Title & Organisation & Company type \\
\hline $\begin{array}{l}\text { Film and } \\
\text { television }\end{array}$ & Nicolai Flesjø (NF) & Head of On-demand & NRK TV & $\begin{array}{l}\text { Broadcaster/ } \\
\text { streaming platform }\end{array}$ \\
\hline $\begin{array}{l}\text { Film and } \\
\text { television }\end{array}$ & $\begin{array}{l}\text { Christian Birkeland } \\
\text { (CB) }\end{array}$ & CEO & TV 2 Sumo & $\begin{array}{l}\text { Broadcaster/ } \\
\text { streaming platform }\end{array}$ \\
\hline $\begin{array}{l}\text { Film and } \\
\text { television }\end{array}$ & $\begin{array}{l}\text { Stine Raste Amundsen } \\
\text { (SRA) }\end{array}$ & $\begin{array}{l}\text { Direct-to- Consumer } \\
\text { Manager }\end{array}$ & $\begin{array}{l}\text { Discovery Network } \\
\text { Norway }\end{array}$ & $\begin{array}{l}\text { Broadcaster/ } \\
\text { streaming platform }\end{array}$ \\
\hline $\begin{array}{l}\text { Film and } \\
\text { television }\end{array}$ & $\begin{array}{l}\text { Tine Austvoll Jensen } \\
\text { (TAJ) }\end{array}$ & CEO & $\begin{array}{l}\text { Discovery Network } \\
\text { Norway }\end{array}$ & $\begin{array}{l}\text { Broadcaster/ } \\
\text { streaming platform }\end{array}$ \\
\hline $\begin{array}{l}\text { Film and } \\
\text { television }\end{array}$ & Børge S. Nielsen (BSN) & Head of Viaplay Norge & Viaplay Norge & $\begin{array}{l}\text { Broadcaster/ } \\
\text { streaming platform }\end{array}$ \\
\hline $\begin{array}{l}\text { Film and } \\
\text { television }\end{array}$ & Trygve Rønningen (TR) & $\begin{array}{l}\text { Head of Channel and } \\
\text { Publisher }\end{array}$ & TV 2 & Broadcaster \\
\hline $\begin{array}{l}\text { Film and } \\
\text { television }\end{array}$ & Håkon Briseid (HB) & Head of Drama & Monster & Production company \\
\hline $\begin{array}{l}\text { Film and } \\
\text { television }\end{array}$ & Fridrik Mar (FM) & Head of Drama & Rubicon TV & Production company \\
\hline $\begin{array}{l}\text { Film and } \\
\text { television }\end{array}$ & Knut Alfsen (KA) & Head of Union & $\begin{array}{l}\text { Norwegian Actor } \\
\text { Association }\end{array}$ & Interest organisation \\
\hline $\begin{array}{l}\text { Film and } \\
\text { television }\end{array}$ & Sverre Pedersen (SP) & Head of Union & $\begin{array}{l}\text { Norwegian Film Asso- } \\
\text { ciation }\end{array}$ & Interest organisation \\
\hline $\begin{array}{l}\text { Film and } \\
\text { television }\end{array}$ & Åse Kringstad (ÅK) & Leader & $\begin{array}{l}\text { The Norwegian Pro- } \\
\text { ducers' Association }\end{array}$ & Interest organisation \\
\hline $\begin{array}{l}\text { Film and } \\
\text { television }\end{array}$ & $\begin{array}{l}\text { Morten Stephanson } \\
\text { (MS) }\end{array}$ & Sales Manager Norway & $\begin{array}{l}\text { Nordisk Film Distribu- } \\
\text { tion }\end{array}$ & Distributor \\
\hline $\begin{array}{l}\text { Film and } \\
\text { television }\end{array}$ & Aage Aaberge (AA) & Producer & Nordisk Film & Production company \\
\hline $\begin{array}{l}\text { Film and } \\
\text { television/ } \\
\text { advertising }\end{array}$ & $\begin{array}{l}\text { Håvard K. Bakken } \\
\text { (HKB) }\end{array}$ & Head of Research & $\begin{array}{l}\text { The Norwegian Adver- } \\
\text { tisers' Association }\end{array}$ & Interest organisation \\
\hline $\begin{array}{l}\text { Film and } \\
\text { television }\end{array}$ & $\begin{array}{l}\text { Nils Ketil Andresen } \\
\text { (NKA) }\end{array}$ & CEO & Nordic Screens & Production company \\
\hline $\begin{array}{l}\text { Film and } \\
\text { television/ } \\
\text { podcast }\end{array}$ & Vilde Batzer (VB) & Head of Podcasts & NRK & Broadcaster \\
\hline Book & Håkon Havik (HH) & CEO & Storytel & Streaming platform \\
\hline
\end{tabular}




\begin{tabular}{|c|c|c|c|c|}
\hline Book & $\begin{array}{l}\text { Ann Kristin Vasseljen } \\
\text { (AKV) }\end{array}$ & Head of Publishing & Fabel/Lydbokforlaget & $\begin{array}{l}\text { Streaming platform/ } \\
\text { publisher }\end{array}$ \\
\hline Book & Lene Røren (LR) & CEO & Ebok.no & Streaming platform \\
\hline Book & Kristenn Einarsson (KE) & CEO & $\begin{array}{l}\text { Norwegian Publishers } \\
\text { Association }\end{array}$ & Interest organisation \\
\hline Book & $\begin{array}{l}\text { Heidi Marie Kriznik } \\
\text { (HMK) }\end{array}$ & Leader & $\begin{array}{l}\text { The Norwegian } \\
\text { Authors' Union }\end{array}$ & Interest organisation \\
\hline Book & Arne Vestbø (AV) & Secretary General & $\begin{array}{l}\text { The Norwegian Non- } \\
\text { Fiction Writers and } \\
\text { Translators Association }\end{array}$ & Interest organisation \\
\hline Book & Einar Ibenholt (EI) & $\begin{array}{l}\text { Head of Strategy and } \\
\text { Development }\end{array}$ & Gyldendal & Publisher \\
\hline Book & Tine Kjær (TK) & $\begin{array}{l}\text { Head of Publishing, } \\
\text { Fiction and Youth }\end{array}$ & Cappelen Damm & Publisher \\
\hline Book & $\begin{array}{l}\text { Tone Krohn Clausen } \\
\text { (TKC) }\end{array}$ & $\begin{array}{l}\text { Head of Strategy, Busi- } \\
\text { ness Development and } \\
\text { Operations }\end{array}$ & Aschehoug & Publisher \\
\hline Book & Jorun Sandsmark (JS) & $\begin{array}{l}\text { Head of Publishing } \\
\text { (Editor in Chief) }\end{array}$ & Kagge & Publisher \\
\hline Book & Eystein Hanssen (EH) & Leader & Author's Union & Interest organisation \\
\hline Book & Elizabeth Sellevold (ES) & Head of Publishing & Vigmostad \& Bjørke & Publisher \\
\hline Music & Live McKay (LMK) & Commercial Director & Universal & Record company \\
\hline Music & Inger Elise Mey (IEM) & $\begin{array}{l}\text { Assistant Director, } \\
\text { Online Media }\end{array}$ & Tono & Interest organisation \\
\hline Music & Herman Foss (HF) & $\begin{array}{l}\text { Advisor, Contracts } \\
\text { [Avtalekonsulent] }\end{array}$ & Tono & Interest organisation \\
\hline Music & Johan Seidefors (JSE) & $\begin{array}{l}\text { Head of Content, Nor- } \\
\text { dics (Senior Editor) }\end{array}$ & Spotify & Streaming platform \\
\hline Music & Sveinung Rindal (SR) & Country Manager & The Orchard & Agency \\
\hline Music & Hans Ole Rian (HOR) & Head of Union & $\begin{array}{l}\text { CREO [Musicians' } \\
\text { Union] }\end{array}$ & Interest organisation \\
\hline Music & Larry Bringsjord (LB) & Chair & Fono & Interest organisation \\
\hline Music & Marte Thorsby (MT) & Managing Director & IFPI Norway & Interest organisation \\
\hline Music & $\begin{array}{l}\text { Marius } \varnothing \text { vrebø-Eng- } \\
\text { moen (MØE) }\end{array}$ & Managing Director & Gramart & Interest organisation \\
\hline Music & Lena Midtveit (LM) & $\begin{array}{l}\text { Senior Manager } \\
\text { (Streaming and } \\
\text { Brands) }\end{array}$ & Sony Music & Record company \\
\hline Music & Kerstin Mangert (KM) & General Manager & Arctic Rights & Publisher \\
\hline
\end{tabular}




\section{Cross-industrial notions of opportunities and challenges}

In this analysis, we start with the first research question, looking at what key industry players see as the main opportunities and challenges of streaming.

\section{Opportunities}

All the informants were eager to stress that streaming offered several opportunities, for both industry players and the audience. For some, particularly those representing new streaming companies (e.g., Spotify and Nordic Screens), the opportunities were seen to surpass the challenges. What is more, we found a shared perception of the most crucial streaming opportunities, both within and across industries. We categorise these in four groups: retaining audiences, increasing content availability, developing new revenue streams, and creating new formats or ways of presenting content.

The first opportunity for retaining audiences relates to the way streaming allows industry players to connect (and re-connect) with audiences turning to new streaming platforms for their music, film, television and book consumption. Informants from all four industries highlighted how streaming could strengthen industry-audience relations by reaching audiences who were otherwise hard to access. Many stressed how streaming was particularly important for reaching younger audiences, thus reflecting the more general industry lore of an "escaping youth" (Davidson et al., 2020). For instance, all but one (37 of 38) agreed with the claim that "Young people have a completely different media consumption than older media users". Some informants even noted how streaming could lead to more consumption, as streaming services increased the portfolio of content (introducing long back-catalogues and archives of content) and allowed audiences to stream at their own pace (see also, Hagen, 2015; Johnson, 2019). Relatedly, several informants from the book industry addressed the way streaming allowed them to access a larger part of an audiences' "media day": Listening to audiobooks allowed audiences to consume books while also doing other activities. Many also noted streaming services as a way of reaching a more international audience. For instance, the majority of the informants (32 of 38) agreed with the claim that "Streaming allows for a larger, global audience".

While all informants acknowledged a change in audience behaviour, music and television informants operated with a perception of more deeply embedded audience shifts. Audiences were moving from consuming CD and linear television to music and television streaming (see also, Lüders et al., 2021). Furthermore, many informants described streaming as an almost unstoppable force to which they had to adapt, willingly or not. Consequently, music and television informants tended to describe the exploration of streaming as essential in order to grow and survive. As one television informant said, "If we aim to stay big and important, we need to be where the audience is-on streaming platforms" (CB, television). Similarly, one music informant stated, "To spread your music, you need to use streaming platforms and Spotify" (HOR, music). As a general observation, many music and television informants described "streaming as the place to be" (KA, film and 
television). In contrast, film and book informants described streaming more as an add-on than a replacement to existing consumption modes-going to the cinema and reading paper books.

The second opportunity, increasing content availability, is related to the way streaming allows for increased accessibility and flexibility in distribution and use, benefiting both audiences and industry players by allowing more choice and convenience (see also Johnson, 2020; Lüders, 2019). As one television informant explained, "I think streaming begins with an opportunity for the consumer; you can choose for yourself" (NF, television). All the informants (38 of 38) agreed with the claim that "Streaming services make media content more accessible", and all but one (37 of 38) agreed with the claim that "Streaming makes it easier for audiences to find content tailored to their tastes and interests".

Many informants also highlighted how streaming allowed for large back-catalogues that increase the lifetime of albums, films, series, and book titles. Many music and television informants stressed how streaming (and digitalisation) boosts the number of industry players and the amount of content they can offer. In the words of the informant from Spotify, "What I think is the absolute advantage [of streaming] is accessibility, which increases all the time" (JSE, music). Informants representing "new" media companies often stressed how streaming lowered entry barriers, allowing newcomers to enter markets previously controlled by incumbents (NKA, television). Some informants from the music industry even used the term "democratisation", indicating the way that streaming "revolutionises the use of music and democratises the music industry" (IEM, music). The argument was that streaming made it possible for "everyone" to produce and distribute music, and that revenues would reflect played songs rather than sold albums. However, as many hastily added, the increased ability to produce and distribute lead to a surplus of content, making the competition harder: "Streaming democratises the possibilities of releasing music in ways we haven't seen before. (...) The challenge is that when everyone can do so, there is an awful lot of people doing it" (MØE, music).

The third opportunity relates to how streaming offers the potential for new revenue streams. Informants described how streaming was a much-needed supplement to the decline in income from previous sales of CDs, DVDs, and printed books. In the television industry, some informants even described a "golden age" where new streaming platforms (such as Netflix, HBO Nordic) were new commissioners of content, increasing the numbers of buyers in national markets (FM, television, $\mathrm{HB}$, television). As explained by one informant, "Streaming gives Norwegian producers extra business opportunities. More content commissioners means we can produce more" (ÅK, film and television). Many of the informants even supported the notion that revenues would increase in the future: 28 of 38 informants agreed with the claim "I believe the profitability of the streaming market will increase over time". Again, however, many suggested that the audiences were the true winners of streaming: All the informants (38 of 38) agreed with the claim that "The streaming business model gives the audience value for money". 
Several informants also highlighted the benefit of the streaming subscription model. According to one television informant, this model made it easier to forecast business cases, since decision-making was built on subscribers and big data (BSN, television). Relatedly, many informants emphasised the importance of analysing user data, and almost all (37 of 38) agreed with the claim that "Analysis of user data will be even more important in the future". In the book industry, some informants even stressed how the streaming subscription model represented a new revenue model altogether. For them, the subscription model increases readers' exploration of titles and authors, as this model "reduced the cost of testing to zero" (El, book). This, in turn, might lead to an increased interest in books in general, which would also benefit the sales of printed books.

Finally, many informants stressed how streaming allowed for new formats or ways of presenting content. As such, streaming invited new types of content altogether. It reflected a general perception of change associated with streaming. For instance, the overwhelming majority of the informants (36 of 38) agreed with the claim that "Streaming is changing the way my industry produces content". For example, one music informant noted TikTok as a new platform for spreading music and increasing the streams of particular songs, changing the music industry along the way. Other informants noted podcasts as a new streaming format where several players and markets now intersect. Similarly, informants from the film and television industries were eager to explain how streaming expanded storytelling techniques. According to one informant, "Streaming is perhaps one of the best things happening to television. Storytelling was getting monotonous, but streaming allows for new and exciting ways of telling stories" (NF, television). Similarly, one film informant highlighted how streaming becomes "artistically significant" as people watch films in more diverse ways than before, allowing for "new dramaturgical tools": "It's a new artistic way of telling stories, and it allows for bigger and more epic stories" (KA, film and television).

\section{Challenges}

Turning from the opportunities to the challenges, we find a shared understanding both within and across industries that streaming also poses challenges. We categorise these challenges in three groups: uneven distribution of power, uncertain sustainability of business models, and the cost and complexity of rights management.

The first challenge of the uneven distribution of power relates to how streaming is associated with global platforms with international operations, big budgets, and massive content catalogues (Van Dijck et al., 2018), transforming the markets from national to global in scope. Compared with national and regional players, global streaming providers are powerful, and have substantial capital to invest (Lobato, 2019; Vonderau, 2017). Although the competition from global platforms was most profoundly noted by informants from the music, television and film industries - typically using Netflix and Spotify as references - platform power was a key issue across all four industries. Informants highlighted 
the power that platform owners (global or regional) possess by controlling user data, dictating terms, determining what is being made visible to the audience and taking the lion's share of profits. Many informants also noted how global streaming providers are less regulated than traditional distribution channels, echoing findings from previous platform studies (Evens \& Donders, 2018; Plantin \& Punathambekar, 2019; Van Dijck et al., 2018).

Some platform providers are commissioners and buyers of content, and identified the new platforms as a positive influence in the industries (see above). Nevertheless, many informants described market structures favouring buyers over sellers, not least because these platforms dictate financial terms. Several informants described the shift from transactional sales to streaming as entailing a transfer of power from production actors and traditional intermediaries like publishers, broadcasters and record companies, to streaming platforms. For instance, informants in both the music and book industries described streaming platforms as "the new gatekeepers" (KE, book), thus nuancing the above notion of streaming as a force of democratisation. Relatedly, several informants stressed how streaming providers keep a tight lid on both financial and user data, and called for more transparency in sales numbers and revenues. While insights into usage and audience numbers have traditionally been essential in order to calculate royalties and remunerations, these figures in streaming are considered the property of the streaming provider (Maasø \& Hagen, 2019). Transparency is also regarded as essential in order to hinder fraudulent practices. Nevertheless, our study indicates that the notion of platform power is ambiguous and under construction. For instance, only 15 of 38 agreed with the claim that "Norwegian content disappears in streaming services" (23 disagreed), and only a small majority (22 of 38 ) agreed with the claim that "In the future, we will have a global streaming industry where a few players control all key positions".

The power of the platforms is also connected with the second challenge, the uncertain sustainability of business models. Although streaming is a potential source of income, as described above, many informants were concerned about the sustainability of the streaming business models, especially as audiences seem less willing to pay good money for cultural products in digital formats. Streaming services have comparable prices across the industries, not departing much from the level established when streaming first emerged over a decade ago. This is most visible in the music industry, as one informant saw it: "When the big streaming services launched some ten years ago, they settled for a psychological price level at about 99 kroner [10 USD], and that's where they have been stuck since, meaning that they have reduced real prices year by year" (HF, music). Although Spotify has since increased its subscription price in Norway (from 99 to 109 and later 119 NOK), the pricing of music streaming services is characterised by more stable and lower prices than for television and film services (see Colbjørnsen et al., 2021 for an analysis of streaming prices). Informants in the music industry were also concerned about free or advertising-funded streaming platforms (YouTube and Spotify Free), that bring little revenue into the value chain. As summarised by one informant from the music industry, 
"Streaming is a business model, but the question is whether it pays off" (IEM, music). Another informant echoed the sentiment, "You need to be on streaming platforms to distribute your music. But as we are painfully aware, income is absent for 90-95 per cent of the content on streaming platforms" (HOR, music). Similarly, many informants were concerned about how to distribute revenue. This discussion is about whether to use the so-called "revenue share" ("pro rata") or "user-centric" model (Nordgård, 2016). The revenue share model favours big artists/authors, according to our informants, while the user-centric model may be more beneficial to smaller content creators. According to a publisher in the book industry, revenue share models tend to "push risk towards the back of the value chain to the author and publisher" (El, book).

Across the four industries, streaming providers, along with audiences, were seen as the real beneficiaries of the streaming business model. According to one informant from the streaming service Storytel, making sure rights holders can earn "a decent income from their new products" was defined as a primary objective ( $\mathrm{HH}$, book). Finding fair financial models is challenging, not least when a significant part of the streaming service's business model involves collecting user data (as for YouTube, but also for Spotify and Netflix) (Maasø \& Hagen, 2019). In this context, it was seen as difficult for rights holders to find a level offering fair and proportionate remuneration, "charging a percentage on user data revenues", as one informant said (IEM, music). Across industries, many informants were concerned about revenues lost from physical formats and transactional sales to bundling and subscriber-based models. For instance, DVD sales for television and film generate substantial revenues that streaming has yet to replace. Similarly, informants from the book industry, including representatives from the streaming providers themselves, were not interested in seeing streaming completely displace the more profitable print and ebook markets.

Finally, many informants stressed how streaming increased the costs and complexity of rights management. Rights management has always been complicated, but streaming raised the bar and pushed industry players to agree about new rules and routines (Kjus, 2019; Sundet, 2021, ch. 2). Furthermore, many informants connected the challenge of rights management to the overall need for content, and stressed the advantages of "being big" (economies of scale). Being big was used both in the sense that streaming services prefer dealing with larger packages, and in the sense that catalogue size is an important part of the value proposition: "Streaming is a volume game", as one informant expressed it. Having control over an extensive portfolio of rights was thus seen as necessary across industries. Some actors on the content production side (television producers, book publishers) also have stakes in streaming services. Several informants indicated this position as a strategic advantage for the content producers and the streaming providers. For the content producers, it gives an outlet for distributing content; for the streaming services, it means having control over content supply and rights.

The relationship between content production and streaming distribution is different in the four industries. Music services typically provide overlapping content catalogues, 
while television/film and book streaming services have exclusive content as prominent features. These latter industries are also more fragmented, with more platforms vying for a piece of the streaming pie. This is a challenge for creators and content producers in the television, film, and book industries, as it means that accessing the most powerful platform is not a given. Several informants pointed out that similar content offers in the music streaming services means that competition primarily takes place at the level of price, keeping monthly subscription prices down.

\section{Industry lore and sensemaking across industries}

In this analysis, we turn to the second research question, to investigate whether shared notions of opportunities and challenges lead to similar sensemaking notions and similar approaches to finding solutions. In addition to searching for shared notions and industry lore, we examine whether informants look to neighbouring industries for inspiration and best practice.

\section{Lessons}

On a general level, learning from other industries was perceived to be of high importance, and the majority of the informants (36 of 38) agreed with the claim that "I learn a lot by following industries other than my own". Where to look for inspiration and "best practices" varied, but was often correlated with a shared assumption across the industries about which industries are "ahead" and which industries are "behind" in a streaming context (and in the wider context of digitalisation). Perceptions such as these are likely to affect strategies, as media organisations move into uncharted territories. According to the informants, the music industry came first and has progressed the farthest, followed by the television and film industries, with the book industry lagging. It follows that three industries look to music for lessons learned from the industry, which has most emphatically seen a shift from transactions to streaming subscription models. Music informants with extensive experience with streaming (such as those from the major record labels) were also looking outside traditional media industries, taking cues from art directors, branding experts in social media, etc.

While the television, film, and book informants commonly reported that they could learn from the music industry's early experiences with streaming, these lessons were often seen as "worst practice". In other words, informants stressed they were seeking to avoid the unfortunate consequences of the music streaming market. Less revenue distributed to rights holders, unhealthy price competition and a concentration on hits were cited as outcomes of the way the music streaming model is configured. For instance, book industry informants representing author and publisher associations emphasised the importance of standardised contractual arrangements and minimum payments from streaming to create more favourable business opportunities for authors than exist for music artists. 
Film and television informants representing similar interest organisations argued in similar ways. Informants from the music industry were also eager to indicate the challenges of their own industry, and several stressed that being early had its disadvantages: "The music industry took some knocks. The paradigm shift hit us first" (KM, music). Another informant echoed the same sentiment: "We were the first to be thrown into the war, so to speak" (LM, music). Some informants even resisted the notion that the music industry had completed the shift to streaming, accentuating the need to continue the process: "Since 2014, we've tended to see ourselves as finished with the streaming shift. (...) It's stupid and wrong to think we're at the finishing line" (SR, music).

The metaphors used, invoking fighting (e.g. "took some knocks"), sports (e.g. "finishing line") and war (e.g. "thrown into the war") indicate how informants perceived streaming as creating winners and losers. Informants also tended to perceive platform providers and the audience as the biggest "winners" in the shift to streaming. Similarly, the linear innovation lore of who is ahead and who is behind can provide meaning and clarity to confusing developments and changing contexts (Weick, 1995). It also provides a sense of direction and indicates that despite differences, the cultural industries are moving in the same direction. In this industry lore, streaming becomes (part of) the answer to the challenges that media and cultural industries are facing, particularly in the search for digital revenues and user groups. In the music industry, a set of trade stories (Caldwell, 2008) around streaming and its historical emergence have already appeared. Briefly recounting some of these stories, music informants noted lessons learned along the way, but also opportunities missed.

Part of the sensemaking and strategic reasoning of streaming executives also involves finding common reference points: Netflix and Spotify were mentioned as exemplary by many informants, across industries: "They [Spotify] have become a bit like Netflix; they define the category to which everyone else compare themselves" (CB, film and television). The multiple references to Netflix in particular, but also HBO, YouTube and Amazon, indicates how they serve as "representational technologies" (Burroughs, 2019, p. 1), not only within their respective industries, but across industries.

Looking ahead also prompted informants to reflect on transnational differences, indicating that media development occurs in space as well as over time. Many noted Scandinavian streaming habits as among the most mature, paving the way and offering lessons to other nations. In the music industry, for instance, many informants expressed curiosity over how the global streaming music market would change when big markets (e.g., China, Russia, India, Germany, Japan) entered. A similar development seems to be taking place in the Nordic book industries, where ebook and audiobook streaming has a particularly solid position. According to one informant, the Nordics are "a testing laboratory" (El, books). Being ahead in this manner also means that it is difficult to find international markets to learn from. Advanced digital book markets like the US have previously served as exemplary, with the Norwegian actors being able to turn to these as a form of "similar- 
ity heuristics" in decision-making (Read \& Grushka-Cockayne, 2010). As one informant explained: "Previously, we could follow the ebook development in the English-speaking market, with Amazon at the front, and learn from what was taking place. But now, we have no one to look to" (El, books).

\section{Solutions}

Generally, informants highlighted a multitude of solutions to "streaming problems", often related to industry-specific problems. Despite shared assumptions and similar industry lore about streaming, they saw little benefit in drawing explicitly and specifically from neighbouring industries. This may be surprising, considering that streaming is a crossindustry trend, but suggests that, for some, there is no playbook for digital media development.

One reason for the lack of a cross-industrial approach is related to the structure of the different markets, and the diverging industry logics. For instance, for producers of film and television content, streaming services not only offer new distribution platforms, but are vendors and financers. Similarly, while music and book industry actors see streaming as an important new distribution channel (an understatement in the case of music), the opportunities for generating significant revenue are less predictable. This is the result of industry configurations: Television and film rights are bought (licensed) up front, while music and audio books generate royalties based on streaming numbers (see also Herbert et al. 2019). We also found differences in the importance that informants across industries attach to regulation. For instance, music industry informants noted EU (European Union) and supranational policymaking institutions, while book industry informants noted national policy frameworks. In the film and television industry, informants called for mixed policy incentives, such as the international regulation of global platforms in combination with national support schemes.

On a more general level, informants seemed to operate with two main ways of dealing with the challenges at hand, and these two sensemaking approaches are found within all four industries. On the one hand, we have informants stressing how crucial it is to learn from industry mistakes, including from neighbouring markets. As one informant from the film industry explained:

The music industry is ahead of us, so of course we have looked at it. You can question what we've learned, but at least we knew what was going to happen to DVD sales when we saw what happened in the music industry. Today, I follow the book industry, to see what happens there. We always have something to learn from other industries (AA, television and film).

On the other hand, we have informants emphasising uncertainty, and echoing the argument that "nobody knows". This goes back to Caves' (2002) work on creative industries, where he used the term to explain why these industries are so risk aversive. Central to his 
argument was the fact that it is more difficult to predict success (and failure) in the creative industries than in other industries, making creative industries sensitive to previous success stories (see also Havens \& Lotz, 2012, p. 17-19). As one informant in our interviews explained, echoing these sentiments: "No one knows how this is going to play out. (...) Music has had its challenges, and they have created their solutions; the daily press, the weekly press, the film industry, and the television industry have found their solutions" (El, books).

\section{Conclusion}

This article has analysed how key industry players across various cultural industries make sense of, and form notions about, streaming. By combining perspectives on the streaming model with perspectives on industry logics and industry lore, we have discussed how informants across industries perceive streaming opportunities and challenges, and take lessons from neighbouring markets.

A key finding in the article is the collective understandings of opportunities and challenges that industry executives attach to streaming, indicating that key industry players make sense of streaming in similar ways. Although there are many perceived opportunities (retaining the audience, increasing content availability, developing new revenue streams, and creating new formats and ways of presenting stories), streaming challenges are given profound weight: In general, industry players tend to describe streaming as a driver that fundamentally globalises market structures and leads to reduced revenue and unstable market positions. We also find a collective understanding of turmoil, in which informants stress the speed of change as more rapid than previously, and many express doubts about the sustainability of current media business models. This, in turn, leads to a cross-industrial notion of uncertainty in terms of what even the near future will bring. While music, as the most mature industry, may differ from the other three industries in this regard, there is also uncertainty here about what comes after streaming, and the next disruptive technology or platform. Furthermore, many reflect a "nobody knows" attitude regarding the future, and a common response to questions about forthcoming trends are statements such as "that's impossible to know".

Although our findings indicate a collective understanding of the challenges of streaming across industries, we do not find the same set of commonalities in our informants' descriptions of solutions or strategies. Here, various strategies are found, depending on both the type of institution and industry our informants represent. Furthermore, while practically all informants emphasise the need to look to other industries, specific strategies and solutions are more often reached from within one's core industry. Different industry logics might explain the lack of common cross-industrial approaches, and there simply is no "one size fits all". Institutionalised notions of "how to do things" may further cement industry-specific practices and limit the opportunities for learning from others. 
This finding implies that although streaming imposes many of the same challenges in the music, film, television and book industries, specific solutions and practices are still seen as necessary for success and survival.

\section{Acknowledgements}

This article was produced in association with the University of Oslo research project "Streaming the culture industries", funded by the Research Council of Norway (grant number 263076). The authors wish to thank the project group for valuable comments, and thank research assistants Håvard Kiberg, Benedikte Solstad and Eline Rud Wagle.

\section{References}

Ang, I. (1991). Desperately Seeking the Audience. London: Routledge. https://doi.org/10.4324/9780203321454

Beckert, J. (2016). Imagined Futures: Fictional Expectations and Capitalist Dynamics. Cambridge: Harvard University Press. https://doi.org/10.4159/9780674545878

Bruun, H. (2016). The Qualitative Interview in Media Production Studies. Paterson, C., Lee, D., Saha, A. \& Zoellner, A. (Eds.), Advancing Media Production Research. Shifting Sites, Methods, and Politics (pp. 131146). London: Palgrave MacMillan. https://doi.org/10.1057/9781137541949_9

Bruun, H. (2020). Re-Scheduling Television in the Digital Era. London: Routledge.

Burroughs, B. (2019). House of Netflix: Streaming media and digital lore. Popular Communication, 17(1), 1-17. https://doi.org/10.1080/15405702.2017.1343948

Caldwell, J.T. (2008). Production Culture. Industrial Reflexivity and Critical Practice in Film and Television. Durham: Duke University Press. https://doi.org/10.2307/j.ctv11sn72d

Caves, R.E. (2002). Creative Industries. Contracts Between Art and Commerce. Harvard: Harvard University Press.

Colbjørnsen, T. (2015). The accidental avant-garde: Audiobook technologies and publishing strategies from cassette tapes to online streaming services. Northern Lights: Film \& Media Studies Yearbook, 13(1), 83-103. https://doi.org/10.1386/nl.13.1.83_1

Colbjørnsen, T. (2020). The streaming network conceptualising distribution economy, technology and power in streaming media services. Convergence, Online first. https://doi.org/10.1177/1354856520966911

Colbjørnsen, T., Hui, A. \& Solstad, B. (2021). What do you pay for all you can eat? Pricing practices and strategies in streaming media services. Manuscript submitted for publication.

Colbjørnsen, T., Tallerås, K \& Øfsti, M. (2020). Contingent availability: A case-based approach to understanding availability in streaming services and cultural policy implications. International Journal of Cultural Policy, Online first. https://doi.org/10.1080/10286632.2020.1860030

Cunningham, S. \& Silver, J. (2013). Screen Distribution and the New King Kongs of the Online World. London: Palgrave Pivot. https://doi.org/10.1057/9781137326454

D'Arma, A., Raats, T. \& Steemers, J. (2021). Public service media in the age of SVoDs: A comparative study of PSM strategic responses in Flanders, Italy and the UK. Media Culture \& Society, Online first. https://doi.org/10.1177/0163443720972909 
Davidson, P., Bulger, M. \& Madden, M. (2020). Navigating Youth Media Landscape: Challenges and Opportunities for Public Media. New York: Joan Ganz Cooney Centre at Sesame Workshop.

Enli, G. \& Syvertsen, T. (2016). The end of television—again! How TV is still influenced by cultural factors in the age of digital intermediaries. Media and Communication, 4(3), 142-153. http://dx.doi.org/10.17645/mac.v4i3.54t

Evens, T. \& Donders, K. (2018). Platform Power and Policy in Transforming Television Markets. London: Palgrave MacMillan. https://doi.org/10.1007/978-3-319-74246-5

Fagerjord, A. \& Kueng, L. (2019). Mapping the core actors and flows in streaming video services: what Netflix can tell us about these new media networks. Journal of Media Business Studies, 16(3), 166-181. https://doi.org/10.1080/16522354.2019.1684717

Grainge, P. \& Johnson, C. (2015). Promotional Screen Industries. London: Routledge. https://doi.org/10.4324/9781315718682

Hagen, A.N. (2015). Using music streaming services: Practices, experiences and the lifeworld of musicking. Ph.D. thesis, University of Oslo.

Have, I. \& Pedersen, B.S. (2020). The audiobook circuit in digital publishing: Voicing the silent revolution. New Media \& Society, 22(3), 409-428. https://doi.org/10.1177/1461444819863407

Havens, T. (2008). The Evolution of Industry Lore in African American Television Trade. Montreal, QC: International Communication Association.

Havens, T. \& Lotz, A.D. (2012). Understanding Media Industries. Oxford: Oxford University Press.

Havens, T., Lotz, A.D. \& Tinic, S. (2009). Critical media industry studies: A research approach. Communication, Culture \& Critique, 2, 234-253. doi:10.1111/j.1753-9137.2009.01037.x

Herbert, D., Lotz, A.D. \& Punathambekar, A. (2020). Media Industry Studies. Cambridge: Polity.

Herbert, D., Lotz, A.D. \& Marshall, L. (2019). Approaching media industries comparatively: A case study of streaming. International Journal of Cultural Studies, 22(3), 349-366.

https://doi.org/10.1177/1367877918813245

Hesmondhalgh, D. (2019). The Cultural Industries. London: Sage Publication.

Johnson, C. (2019). Online TV. London: Routledge. https://doi.org/10.4324/9781315396828

Kiberg, H. (2020). Personaliserte anbefalinger og musikalsk mangfold - en umulig kombinasjon? Norsk medietidsskrift, 107(3), 1-18. https://doi.org/10.18261/ISSN.0805-9535-2020-03-03

Kjus, Y. (2018). Live and Recorded: Music Experience in the Digital Millennium. London: Palgrave MacMillan. https://doi.org/10.1007/978-3-319-70368-8

Kjus, Y. (2019). The use of copyright in digital times. A study of how artists exercise their rights in Norway. Popular Music and Society, Online first. https://doi.org/10.1080/03007766.2019.1698206

Kompare, D. (2006). Publishing Flow. DVD Box Sets and the Reconception of Television. Television \& New Media, 7(4), 335-360. https://doi.org/10.1177/1527476404270609

Lobato, R. (2019). Netflix Nations. The Geography of Digital Distribution. New York: New York University Press. https://doi.org/10.1093/joc/jqz050

Lotz, A.D. (2017). Portals: A Treatise on Internet-Distributed Television. Michigan: Maize Books. https://doi.org/10.3998/mpub.9699689

Lüders, M. (2019). Pushing music: People's continued will to archive versus Spotify's will to make them explore. European Journal of Cultural Studies, Online first. https://doi.org/10.1177/1367549419862943

Lüders, M., Sundet, V.S. \& Colbjørnsen, T. (2021). Towards streaming as a dominant mode of media use? A user typology approach to music and television streaming. Nordicom Review, 42(1), 35-57. https://doi.org/10.2478/nor-2021-0011

Maasø, A. \& Hagen, A. (2019). Metrics and decision-making in music streaming. Popular Communication, 18(1), 18-31. https://doi.org/10.1080/15405702.2019.1701675 
Miège, B. (1989). The Capitalization of Cultural Production. New York: International General.

Moseng, J.S. (2017). The Film and Television Industries in Norway. Bakøy, E., Puijk P. \& Spicer, A. (Eds.) Building Successful and Sustainable Film and Television Businesses (pp. 21-45). Bristol: Intellect.

Nordgård, D. (2016). Lessons from the world's most advanced market for music streaming services. Wikström, P. \& DeFillippi, R. (Eds.) Business Innovation and Disruption in the Music Industry (pp. 175-190). London: Edward Elgar Publishing. https://doi.org/10.4337/9781783478156.00017

Plantin, J-C. \& Punathambekar, A. (2019). Digital media infrastructures: Pipes, platforms, and politics. Media, Culture \& Society, 41(2), 163-174. https://doi.org/10.1177/0163443718818376

Read, D. \& Grushka-Cockayne, Y. (2010). The similarity heuristic. Journal of Behavioral Decision Making, 24(1), 23-46. https://doi.org/10.1002/bdm.679

Spilker, H.S. (2018). Digital Music Distribution: The Sociology of Online Music Streams. London: Routledge. https://doi.org/10.4324/9781315561639

Spilker, H.S. \& Colbjørnsen, T. (2020). The dimensions of streaming: Towards a typology of an evolving concept. Media, Culture \& Society, 42(7-8), 1210-1225. https://doi.org/10.1177/0163443720904587

Sundet, V.S. (2021). Television Drama in the Age of Streaming. Transnational Strategies and Digital Production Cultures at the NRK. London: Palgrave Pivot. https://doi.org/10.1007/978-3-030-66418-3

Sundet, V.S. \& Ytreberg, E. (2009). Working notions of active audiences: Further research on the active participant in convergent media industries. Convergence, 15(4), 383-90. https://doi.org/10.1177/1354856509342339

Tattersall Wallin, E. \& Nolin, J. (2020). Time to read: Exploring the timespaces of subscription-based audiobooks. New Media \& Society, 22(3), 470-88. https://doi.org/10.1177/1461444819864691

Thompson, J.B. (2010). Merchants of Culture: The Publishing Business in the Twenty-First Century. Cambridge: Polity Press

Tryon, C. (2015). TV got better: Netflix's original programming strategies and binge viewing. Media Industries Journal, 2(2), 104-116. https://doi.org/10.3998/mij.15031809.0002.206

Van Dijck, J., Poell, T. \& de Waal, M. (2018). The Platform Society. Public Values in a Connective World. Oxford: Oxford University Press. https://doi.org/10.1093/oso/9780190889760.001.0001

Vonderau, P. (2017). The Spotify effect: Digital distribution and financial growth. Television \& New Media, 20(1), 3-19. https://doi.org/10.1177/1527476417741200

Weick, K. E. (1995). Sensemaking in Organizations. London: Sage.

Wikström, P. (2013). The Music Industry. Digital Media and Society Series. Cambridge: Polity Press.

Vilde Schanke Sundet

Researcher

Department of Media and Communication

University of Oslo

v.s.sundet@media.uio.no

Terje Colbjørnsen

Associate Professor

Department of Archivistics, Library and Information Science

OsloMet

terjec@oslomet.no 